\title{
Gambaran Kebutuhan Psikologis pada Anak dengan Gangguan Emosi dan Perilaku (Tinjauan Kualitatif dengan Art Therapy sebagai Metode Penggalian Data) A.A.Ayu Wulan Dwi Anggaswari dan I.G.A.P. Wulan Budisetyani \\ Program Studi Psikologi, Fakultas Kedokteran, Universitas Udayana wulananggaswari@gmail.com
}

\begin{abstract}
Abstrak
Dalam proses tumbuh kembang anak akan timbul kebutuhan-kebutuhan pada diri anak yang harus dipenuhi. Adapun kebutuhan-kebutuhan tersebut salah satunya adalah kebutuhan psikologis. Kebutuhan tersebut mutlak diperlukan, bahkan memegang peranan penting untuk memberikan landasan dari mana pertumbuhan dan perkembangan aspek fisik, kognitif dan sosioemosional dilanjutkan. Ketika anak tidak mampu memperoleh kebutuhannya dengan baik, maka akan muncul masalah penyesuaian diri pada anak, salah satunya adalah gangguan emosi dan perilaku. Untuk dapat mengetahui kebutuhan psikologis pada anak dengan gangguan emosi dan perilaku, dapat menggunakan art therapy. Art therapy dapat digunakan sebagai media berkomunikasi karena anak dengan gangguan emosi dan perilaku memiliki kesulitan untuk mengungkapkan atau mengenali emosi yang sedang dirasakannya. Tujuan dari penelitian ini adalah untuk mengetahui kebutuhan psikologis pada anak dengan gangguan emosi dan perilaku melalui wawancara dan observasi dengan menggunakan metode art therapy.

Penelitian kualitatif ini menggunakan pendekatan studi kasus. Teknik pengambilan sampel yang digunakan adalah purposive sampling. Subjek dalam penelitian ini adalah seorang anak perempuan berusia 12 tahun dengan gangguan emosi dan perilaku. Teknik penggalian data yang digunakan dalam penelitian ini adalah observasi, wawancara dengan menggunakan media art therapy dan catatan lapangan. Data yang terkumpul dianalisis menggunakan teknik analis studi kasus menurut Cresswell (2007).

Berdasarkan hasil analisis data, ditemukan bahwa terdapat 23 kategori yang dapat dikelompokan menjadi tiga pola. Pola-pola tersebut adalah 1. faktor penyebab anak dengan gangguan emosi dan perilaku; 2. karakteristik psikologis; dan 3. kebutuhan psikologis pada anak dengan gangguan emosi dan perilaku.
\end{abstract}

Kata Kunci: art therapy, kebutuhan psikologis, anak, gangguan emosi dan perilaku

\begin{abstract}
In the process of child development, Children have needs and it's has to be filled. One of these needs called psychological needs. Psychological needs are a very important role which can give an impact to the growth and development of physical, cognitive, and socio-emotional. When children are not able to obtain their needs, it would cause adjustment problems and one of the problems is emotional and behavioral disorders. There are so many way to detect children with emotional and behavioral disorders, one of these is art therapy. Art therapy can be used as a communication media for children with emotional and behavioral disorders which have difficulty to express or recognize emotions. The purpose of this study is for knowing the psychological needs of children with emotional and behavioral disorders through interview and observation with art therapy.
\end{abstract}

This qualitative study uses a case study approach. The sampling technique of the study was purposive sampling. Subject in this study was a 12-year-old girl with emotional and behavioral disorders. The data was collected with observation, filed note and interview by using art therapy as a media. The collected data are analyzed according to Cresswell's theory (2007).

Based on the results of data analysis, it was found that there are 23 categories which can be classified into three patterns. These patterns are 1. the causes of children with emotional and behavioral disorders; 2. psychological characteristics; and 3. the psychological needs of children with emotional and behavioral disorders.

Keywords: Art therapy, Psychological needs, Child, Emotional and Behavioral Disorders 


\section{LATAR BELAKANG}

Memiliki anak yang sehat dan memiliki tumbuh kembang yang baik merupakan dambaan bagi setiap pasangan suami istri yang telah menikah. Anak merupakan berkah yang sangat luar biasa, karena anak akan menjadi generasi penerus dalam keluarga. Seorang anak yang dikatakan tumbuh dan berkembang secara normal dan sehat merupakan anak-anak yang berkembang secara fisik, kognitif, sosial dan emosi dengan baik dan sesuai dengan tahapan perkembangan usianya seperti yang dikemukan oleh The UN dalam Rights of The Child (Fawcett, 2000).

Di Negara-negara bagian barat, terdapat berbagai teori tahapan perkembangan, seperti teori tahapan perkembangan Piaget atau Erikson, yang dimana tahapan perkembangan tersebut memetakan kemajuan perkembangan anak secara sistematis untuk menjadi individu dewasa yang matang, rasional, dan kompeten (Fawcett, 2000). Tujuan dari tahapan perkembangan tersebut adalah untuk mengidentifikasi tahapan-tahapan kronologis anak dalam mengikuti urutan perkembangan yang normal. Orangtua memiliki harapan dan cita-cita agar anak mereka dapat berkembang dengan maksimal, sehingga anak tersebut mampu dan berhasil dalam memenuhi tugas-tugas perkembangan yang berlaku umum untuk setiap umur atau sesuai dengan fase perkembangan yang akan atau sedang dilalui oleh anak (Atmodiwirjo, 2008).

Selama proses perkembangan anak menjadi dewasa seutuhnya, terdapat kebutuhan-kebutuhan dasar atau keinginan anak untuk menjadi sesuatu (Gunarsa, 2008). Maslow (dalam Gunarsa, 2008) membagi kebutuhan dasar individu menjadi dua kelompok, yaitu kebutuhan primer atau kebutuhan fisologis seperti makan dan minum, serta kebutuhan sekunder atau kebutuhan psikologis seperti kebutuhan akan rasa aman. Kebutuhan primer atau fisiologis dan kebutuhan sekunder atau psikologis akan dapat terpenuhi dengan cara individu melakukan tindakan atau perilaku tertentu. Seperti misalnya untuk memenuhi kebutuhan fisiologis, ketika individu merasakan lapar, maka individu akan berperilaku tertentu untuk mendapatkan sesuatu yang bisa dimakan, sedangkan ketika individu membutuhkan rasa aman, maka individu akan berperilaku tertentu untuk memperoleh perasaan dicintai, diterima, didukung dan dihargai oleh lingkungan sekitar. Kebutuhan psikologis terkait kebutuhan akan rasa aman tersebut merupakan kebutuhan yang sangat penting dipenuhi pada masa perkembangan anak setelah kebutuhan primer atau kebutuhan fisiologis terpenuhi, kerena pemenuhan kebutuhan rasa aman tersebut akan mempengaruhi perkembangan psikologis anak baik dari segi emosi, mental maupun kepribadian. Ketika anak berhasil memenuhi kebutuhan psikologis, maka anak akan matang secara emosi dan perilaku dimana kematangan emosi dan perilaku tersebut akan berpengaruh terhadap kemampuan anak dalam belajar dan bersosialisasi dengan lingkungan sekitar.
Faktanya, kebutuhan-kebutuhan dasar tersebut memang mutlak diperlukan, bahkan memegang peranan penting untuk memberikan landasan dari mana pertumbuhan dan perkembangan aspek lain dilanjutkan (Gunarsa, 2008). Feist \& Feist (2010) juga mengungkapkan jika tidak terpenuhinya salah satu dari kebutuhan-kebutuhan mendasar dapat mengarah pada beberapa macam penyakit. Maslow (dalam Feist \& Feist, 2010) berasumsi bahwa semua orang dimanapun termotivasi oleh kebutuhan dasar yang sama, sehingga dapat dikatakan bahwa motivasi merupakan faktor utama dalam mendorong individu untuk memenuhi kebutuhan dasar diri sendiri. Makmun (dalam Efendi, 2008) menjelaskan bahwa dalam setiap proses pemenuhan kebutuhan, individu seringkali harus berhadapan dengan sejumlah alternatif, baik yang berkenaan dengan instrumental behavior (kemungkinan tindakan yang akan ditempuh) maupun goals (tujuan yang hendak dicapai) dengan memperhitungkan untung ruginya. Apabila individu mampu menyelesaikan rintangan yang menjadi hambatan dalam upaya untuk memenuhi kebutuhan sebagai dasar dalam proses penyesuaian diri, maka individu telah melakukan tindakan penyesuaian yang sehat dan rasional sehingga dapat mencapai tujuan. Akan tetapi, jika individu tidak dapat mengatasi tantangan yang menghadang maka individu akan mengalami kekecewaan yang mendalam atau frustrasi. Tantangan sebagai penyebab timbulnya frustrasi tersebut dapat bersumber pada orang lain, peristiwa tertentu, diri pribadi dan lain-lain.

Adanya pengalaman-pengalaman yang mengecewakan atau frustrasi tersebut yang menimpa diri seorang anak pada masa perkembangannya akan memudahkan timbulnya masalah gangguan penyesuaian diri dikemudian hari (Atmodiwirjo, 2008). Salah satu bentuk gangguan penyesuaian diri yang dapat dialami oleh anak-anak adalah gangguan emosi dan perilaku.

Menurut Somantri (2007), anak dengan gangguan emosi dan perilaku merupakan anak yang kurang dapat atau mengalami kesulitan dalam menyesuaikan diri dengan baik terhadap lingkungannya, dan hal ini akan mengganggu situasi belajarnya. Penelitian Kauffman dan Landrum (dalam Hallahan, Kauffman \& Pullen, 2009) pada beberapa kota di Amerika Serikat menunjukkan bahwa terdapat enam hingga 10 persen anak-anak dan remaja yang bersekolah di sekolah anak berkebutuhan khusus dan umum mengalami gangguan emosi dan perilaku yang serius. Anak dengan gangguan emosi dan perilaku cenderung memiliki kepribadian yang kurang percaya diri, menunjukkan sikap curiga terhadap orang lain, rendah diri, dan sebaliknya yaitu dengan menunjukkan sikap permusuhan terhadap lingkungan atau otoritas, mengisolasi diri, kecemasan yang berlebihan, tidak memiliki ketenangan jiwa, dan sering melakukan perkelahian atau bentrokan (Efendi, 2008). 
Peran orangtua sangatlah penting dalam membantu anak memenuhi kebutuhan-kebutuhan dasar, salah satunya adalah kebutuhan psikologis. Delphie (2006) menjelaskan hambatan yang ada pada anak dengan gangguan emosi dan perilaku pada usia sekolah dasar atau taman kanak-kanak, umumnya berkaitan dengan sering terjadinya konflik dengan orangtua, dengan saudara atau pasangan saudara kembarnya, sehingga anak dengan gangguan emosi dan perilaku mempunyai perwatakan yang keras, menyangkut perilaku yang lekas marah, serta mempunyai pola tidur dan makan yang tidak pada umumnya. Umumnya, apabila anak sering mendapatkan tanggapan-tanggapan negatif dari keluarga, sekolah atau orang lain dalam lingkungan kehidupan yang dijalani, akan menyebabkan anak menjadi lebih agresif, dan lebih sering menghindarkan diri dari kerumunan orang-orang di sekitarnya. Adanya tekanan-tekanan yang sering terjadi di masyarakat terhadap anak, ditambah dengan ketidakberhasilan anak bersangkutan dalam pergaulan lingkungan sekitar juga sering menjadi penyebab perilaku-perilaku yang menyimpang. Geddes, D. (dalam Delphie, 2006) menyatakan bahwa para ahli psikoanalisis mempercayai bahwa interaksi negatif yang terjadi sejak usia dini antara orangtua dan anak merupakan penyebab utama dari permasalahan-permasalahan yang berkaitan dengan kelainan emosi dan perilaku yang serius. Gunawan (2013) menyatakan bahwa salah satu faktor penyebab munculnya gangguan emosi dan perilaku pada anak adalah karena adanya konflik antara orangtua dan anak. Dengan demikian, para orangtua memiliki tanggung jawab yang besar dalam memperhatikan, memahami, dan memenuhi kebutuhan-kebutuhan baik fisiologis maupun psikologis pada anak mereka. Menurut Missa (2014), keluarga, terutama orang tua, merupakan kebutuhan paling mendasar pada diri seorang anak. Meier (dalam Missa, 2014) menjelaskan bahwa seorang anak akan berkembang menjadi orang dewasa yang matang dan bahagia, baik secara emosi dan rohani, jika berada di dalam keluarga yang sehat secara mental.

Terdapat beberapa cara yang dapat dilakukan untuk mengatasi dan membantu memahami anak dengan gangguan emosi dan perilaku, antara lain yaitu melalui cognitive behavior therapy (CBT), play therapy, dan art therapy (Pawitri, 2014). Anak dengan gangguan emosi dan perilaku cenderung mengalami kesulitan dalam mengekspresikan perasaan atau keinginan. Oleh karena itu, penelitian ini menggunakan media art therapy sebagai metode dalam berkomunikasi antara peneliti dengan anak dengan gangguan emosi dan perilaku.

Menurut The British Association of Art Therapists (2014), art therapy merupakan bentuk psikoterapi yang menggunakan media seni sebagai modal utama untuk berkomunikasi. Tujuan keseluruhan dari kegiatan art therapy ini adalah untuk memungkinkan individu untuk berubah dan tumbuh pada tingkat pribadi melalui penggunaan bahan-bahan seni di lingkungan yang aman dan memfasilitasi. Hal tersebut menawarkan kesempatan untuk berekspresi, berkomunikasi dan dapat sangat membantu untuk individu yang merasa sulit untuk mengungkapkan pikiran dan perasaan secara lisan.

Menurut Pawitri (2014), art therapy memiliki banyak keunggulan dalam membantu dan memahami anak dengan gangguan emosi dan perilaku. Selain dapat diterapkan pada berbagai kalangan usia, art therapy juga dapat dilakukan dengan berbagai cara, antara lain dengan cara melukis, menggambar, mewarnai, membuat patung atau membuat tembikar. Art therapy yang paling sederhana untuk diterapkan adalah melukis, menggambar dan mewarnai. Berdasarkan hasil penelitian yang dilakukan oleh Adriani \& Satiadarma (2011) mengenai efektivitas art therapy dalam mengurangi kecemasan pada remaja pasien leukemia menunjukkan bahwa art therapy efektif dalam mengurangi kecemasan pada pasien leukemia. Melalui proses art therapy yang dilakukan dengan menggambar, remaja pasien leukemia mampu mengekspresikan gejolak perasaan cemas sehingga dengan demikian, beban kecemasan menjadi berkurang. Menurut Hirawan (2014), secara sosial dan emosional, kegiatan menggambar dan mewarnai dapat melepaskan perasaan tegang dan mengurangi kecemasan, pemrosesan kepercayaan diri, memfasilitasi identifikasi emosi dan ekspresi, serta kesadaran akan individualitas dan keunikan. Selain itu, secara komunikasi, melalui menggambar dan mewarnai, anak-anak dapat mengembangkan ekspresi nonverbal, emosi, menyalurkan ide-ide, mempromosikan hubungan dan interaksi dengan orang lain, serta kesempatan untuk menyampaikan ekspresi verbalnya secara spontan.

Berdasarkan pemaparan diatas, maka penelitian ini peneliti menggunakan art therapy sebagai metode dalam melakukan wawancara dan observasi untuk melihat gambaran kebutuhan psikologis pada anak dengan gangguan emosi dan perilaku karena mengingat anak dengan gangguan emosi dan perilaku cenderung sulit dalam mengungkapkan perasaan atau emosi yang dirasakannya dengan baik dan tepat.

Penelitian ini bertujuan untuk mengetahui bagaimana art therapy sebagai metode dalam berkomunikasi dapat membantu mengungkap dan memahami kebutuhan psikologis pada anak dengan gangguan emosi dan perilaku.

\section{METODE PENELITIAN}

\section{Pendekatan}

Penelitian ini menggunakan metode penelitian kualitatif dengan desain studi kasus. Menurut Patton (dalam Ahmadi, 2014), metode kualitatif digunakan untuk memahami fenomena yang sedang terjadi secara alamiah (natural). Bogdan \& Biklen (dalam Ahmadi, 2014) menyatakan penelitian studi kasus merupakan suatu kajian yang rinci tentang satu latar, atau subjek tunggal, atau satu tempat 
penyimpanan dokumen, atau suatu peristiwa tertentu. Studi kasus bertujuan untuk dapat memberikan informasi tentang kekhawatiran, harapan, fantasi, pengalaman traumatis, latar belakang pendidikan, relasi keluarga, kesehatan mental, untuk dapat memahami pikiran atau perilaku individu (Santrock, 2002).

\section{Kriteria Subjek}

Adapun kriteria subjek yang diperlukan dalam penelitian ini adalah :

1. Anak dengan gangguan emosi dan perilaku

2. Berusia $6-12$ tahun

3. Tinggal bersama orang tua

4. Bersekolah di sekolah umum

Penelitian ini menggunakan teknik Purposive sampling. Purposive sampling merupakan teknik pengambilan sampel sebagai sumber data dengan pertimbangan tertentu (Sugiyono, 2013). Dengan menggunakan pertimbangan pribadi yang sesuai dengan topik penelitian, peneliti memilih subjek sebagai unit analisisnya (Satori \& Komariah, 2014).

\section{Tempat penelitian}

Penelitian ini dilakukan di Turiya School yang berlokasi di jalan Palapa, Denpasar. Turiya School adalah sebuah layanan tumbuh kembang dan pendidikan anak yang berbentuk pelayanan bimbingan belajar plus. Gedung Turiya School memiliki dua tingkat, yaitu satu ruangan belajar di lantai satu, satu tempat belajar di teras belakang, dan dua ruangan di lantai dua. Saat proses wawancara dan observasi dilakukan, peneliti menggunakan dua ruangan, yaitu salah satu ruangan di lantai dua dan tempat belajar di teras belakang.

Dalam pelaksanaannya, peneliti melakukan wawancara dan observasi terhadap subjek dengan menyesuaikan jadwal terapi subjek di Turiya School, yaitu pada hari Senin, Rabu dan Jumat, pukul 14.30 WITA-15.30 WITA. Peneliti melakukan wawancara sebanyak 12 kali dan observasi terhadap subjek sebanyak 14 kali dalam rentang waktu tiga bulan. Sedangkan wawancara dengan significant others, yaitu ibu subjek, guru sekolah dan psikolog yang dilakukan sebanyak satu kali.

\section{Teknik Pengumpulan Data}

Metode pengumpulan data yang paling umum digunakan dalam penelitian kualitatif adalah wawancara dan observasi. Dalam penelitian ini, selain menggunakan metode wawancara dan observasi, peneliti juga menggunakan catatan lapangan agar tidak terdapat fakta-fakta yang terlewatkan.

\section{Wawancara}

Wawancara (interview) adalah proses komunikasi interaksional antara dua pihak dimana salah satu pihak telah memiliki tujuan yang telah ditentukan sebelumnya atau tujuan yang serius, yang di dalamnya terdapat proses bertanya dan menjawab pertanyaan (Stewart \& Cash, 2008). Esterberg (dalam Sugiyono, 2013) mengemukakan beberapa macam wawancara, yaitu wawancara terstruktur, semiterstruktur, dan tidak terstruktur. Dalam penelitian ini, peneliti menggunakan teknik wawancara semi terstruktur.

Subjek yang digunakan dalam penelitian ini merupakan anak dengan gangguan emosi dan perilaku yang cenderung mengalami kesulitan dalam mengekspresikan atau mengungkapkan emosi atau perasaan sehingga sangat sulit untuk melakukan wawancara secara langsung. Maka dari itu, penelitian ini menggunakan art therapy sebagai media yang dapat membantu proses wawancara sehingga anak dengan gangguan emosi dan perilaku dapat dengan bebas mengungkapkan perasaan atau emosi terkait dengan kebutuhan psikologis. Adapun prosedur yang dilakukan yaitu peneliti menyiapkan instrument penelitian berupa pertanyaanpertanyaan tertulis. Selain menyiapkan pertanyaan-pertanyaan, peneliti juga menyiapkan alat bantu rekam serta material lain yang dibutuhkan dalam kegiatan art therapy sebagai sarana yang dapat membantu pelaksanaan wawancara agar dapat berjalan dengan lancar. Dalam penelitian ini, wawancara dilakukan dalam kegiatan art therapy. Peneliti bersama psikolog membuat rancangan kegiatan yang disesuaikan dengan tujuan dari penelitian ini, yaitu untuk mengetahui kebutuhan-kebutuhan psikologis pada anak dengan gangguan emosi dan perilaku. Dalam setiap rancangan kegiatan, terdapat pertanyaan-pertanyaan yang akan diajukan kepada subjek.

Wawancara semi terstruktur ini tidak hanya dilakukan pada subjek, tetapi juga dengan informan atau significant others yang dirasa dapat memberikan informasi terkait dengan kondisi dan kebutuhan psikologis pada subjek sebagai anak dengan gangguan emosi dan perilaku. Berbeda dengan wawancara kepada subjek, wawancara kepada informan tidak dengan metode art therapy.

\section{Observasi}

Syaodih (dalam Satori dan Komariah, 2014) menyatakan bahwa observasi merupakan suatu teknik atau cara mengumpulkan data dengan jalan mengadakan pengamatan terhadap kegiatan yang sedang berlangsung. Jenis observasi yang digunakan dalam penelitian ini adalah observasi partisipatif. Dalam observasi partisipatif, peneliti terlibat dalam kegiatan subjek yang sedang diamati atau yang digunakan sebagai sumber data penelitian (Sugiyono, 2013). Sambil melakukan pengamatan, peneliti ikut melakukan kegiatan yang dikerjakan oleh sumber data, dan ikut merasakan suka dukanya. Pada penelitian ini, observasi 


\section{A. A. A. W. D. ANGGASWARI DAN I. G. P. W. BUDISETYANI}

digunakan secara bersama-sama pada saat melakukan wawancara sehingga peneliti akan mendapatkan data tambahan seperti kegiatan yang dilakukan oleh subjek, penampilan fisik subjek, ekspresi emosi, bahasa tubuh, cara bicara serta aspek non verbal lainnya yang ditunjukkan oleh subjek terkait kebutuhan psikologis. Seperti misalnya melalui kegiatan colored candy go around, subjek menunjukkan perilaku menghindar saat ditanya lebih mendalam mengenai hubungan subjek dengan ibunya.

\section{Catatan Lapangan}

Dalam menggali data melalui observasi dan wawancara, peneliti juga menggunakan catatan lapangan sebagai alat bantu yaitu dengan mencatat ketika peneliti menemukan fakta atau informasi yang dirasa penting dan menarik untuk digali lebih dalam. Catatan lapangan merupakan catatan tertulis mengenai apa yang didengar, dilihat, dialami, dan dipikirkan dalam rangka pengumpulan data dan refleksi terhadap data dalam penelitian kualitatif (Satori \& Komariah, 2014). Catatan lapangan langsung dibuat setelah pengambilan data melalui observasi atau wawancara.

\section{Analisis data}

Stake (dalam Creswell, 2007) mengungkapkan bahwa terdapat empat tahapan analisis data beserta interpretasinya dalam penelitian studi kasus, yaitu: (1) Categorical Aggregation atau pengumpulan kategori, yaitu peneliti mencari suatu kumpulan kategori dari data yang diperoleh dan kemudian peneliti dapat menemukan makna yang relevan dengan isu yang akan muncul; (2) Direct Interpretation atau interpretasi langsung, yaitu setelah terbentuk kategori, peneliti dapat menarik makna dari kategori tersebut tanpa terpengaruh oleh kategori-kategori lainnya. Hal ini merupakan suatu proses dalam menarik data secara terpisah dan menempatkannya kembali secara bersama-sama agar lebih bermakna; (3) peneliti membentuk Pattern atau pola dengan mencari kesepadanan antara dua atau lebih kategori; (4) terakhir, peneliti mengembangkan Naturalistic Generalization atau generalisasi naturalistik yaitu dari analisa data, yaitu generalisasi yang dimana orang atau peneliti lain dapat belajar dari penelitian kasus ini sehingga dapat diterapkan untuk dirinya sendiri atau untuk penelitian selanjutnya.

\section{Teknik Tringulasi}

Pada penelitian ini, peneliti menggunakan triangulasi sebagai uji kredibilitas data. Triangulasi merupakan pengecekan data dari berbagai sumber dengan berbagai cara dan waktu (Satori \& komariah, 2014), sehingga terdapat tiga teknik triangulasi, yaitu : triangulasi sumber, triangulasi teknik pengumpulan data, dan triangulasi waktu.

Triangulasi Sumber digunakan untuk mencari data dari sumber yang beragam yang masih terkait satu sama lain. Selain mendapatkan data dari subjek, peneliti juga melakukan wawancara pada informan yang memiliki kaitan dengan subjek penelitian. Pada penelitian ini, peneliti mewawancarai ibu subjek, guru subjek dan psikolog yang menangani subjek yang peneliti rasa dapat memberikan informasi terkait dengan kondisi sosial dan emosional, serta kebutuhan-kebutuhan psikologis subjek.

Triangulasi teknik adalah penggunaan beragam teknik pengungkapan data yang dilakukan kepada sumber data, yaitu mengecek data kepada sumber yang sama dengan teknik yang berbeda. Penelitian ini menggunakan art therapy sebagai sarana atau media dalam berkomunikasi dengan subjek. Dalam penerapannya, peneliti menggunakan teknik wawancara untuk mengetahui kondisi kebutuhan-kebutuhan psikologis subjek serta melakukan observasi selama kegiatan art therapy berlangsung.

Triangulasi waktu dilakukan dengan cara mengumpulkan data pada waktu dan situasi yang berbeda. Kegiatan art therapy dilakukan beberapa kali sampai informasi atau data yang dibutuhkan dirasa cukup. Dalam kegiatan ini, peneliti akan melakukan wawancara yaitu terdapat beberapa pertanyaan yang menanyakan hal yang sama.

\section{Etika Penelitian}

Terdapat beberapa isu etika yang harus diperhatikan dan disampaikan kepada responden maupun informan dalam penelitian ini. Sebelum penelitian dimulai, peneliti harus menjelaskan mengenai tujuan dan proses pengambilan data kepada subjek dan informan (ibu subjek, guru sekolah subjek dan psikolog yang menangani subjek). Dalam pengambilan data, peneliti diharapkan dapat memahami kondisi subjek dan situasi lingkungan subjek terkait dengan isu-isu sensitive dan sopan santun. Peneliti juga berkewajiban untuk menjelaskan aspek kerahasiaan kepada subjek dan informan , sehingga subjek dan informan dapat merasa aman dan nyaman selama proses penelitian. Apabila pada suatu keadaan tertentu subjek atau informan merasa tidak nyaman akan berlangsungnya penelitian ini, subjek atau informan dapat membatalkan atau mengundurkan diri dalam penelitian ini. Seluruh informasi mengenai isu etik ini diberikan dalam bentuk informed consent dan disetujui bersama dengan menandatangani surat persetujuan.

\section{HASIL PENELITIAN}

Berdasarkan hasil observasi dan wawancara yang telah dilakukan oleh peneliti selama kegiatan art therapy dan didukung dengan pernyataan dari ibu, guru sekolah dan psikolog yang menangani subjek, maka dalam penelitian ini, 
peneliti menemukan terdapat 23 kategori yang berhubungan dengan kebutuhan psikologis pada anak dengan gangguan emosi dan perilaku. Kategori ini dikelompokkan berdasarkan hasil wawancara dengan menggunakan media art therapy dan observasi yang telah peneliti lakukan. Dua puluh tiga kategori tersebut kemudian membentuk tiga pola, yaitu :

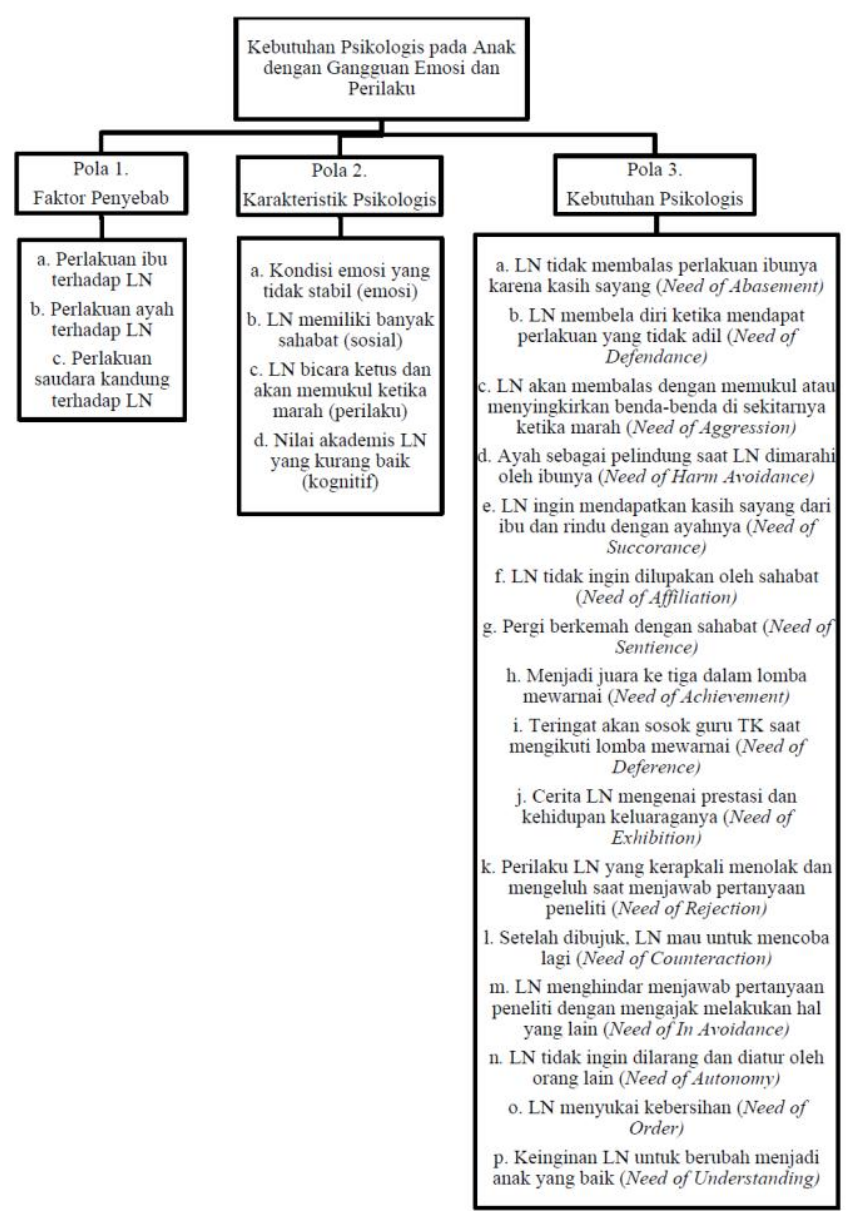

\section{Gambar 2. Hasil Penelitian}

Pola 1. Faktor penyebab anak dengan gangguan emosi dan perilaku
a. Perlakuan ibu terhadap LN
b. Perlakuan ayah terhadap LN
c. Perlakuan saudara kandung terhadap LN

Pola 2. Karakteristik psikologis anak dengan gangguan emosi dan perilaku
a. Kondisi emosi yang tidak stabil (emosi)
b. LN memiliki banyak sahabat (sosial)
c. LN bicara ketus dan akan memukul ketika marah (perilaku)
d. Nilai akademis LN yang kurang baik (kognitif)

Pola 3. Kebutuhan psikologis pada anak dengan gangguan emosi dan perilaku

a. LN tidak membalas perlakuan ibunya karena kasih sayang (Need of Abasement) b. LN membela diri ketika mendapat perlakuan yang tidak adil (Need of Defendance)

c. LN akan membalas dengan memukul atau menyingkirkan benda-benda di sekitarnya ketika marah (Need of Aggression)

d. Ayah sebagai pelindung saat LN dimarahi oleh ibunya (Need of Harm Avoidance)

e. LN ingin mendapatkan kasih sayang dari ibu dan rindu dengan ayahnya (Need of Succorance)

f.LN tidak ingin dilupakan oleh sahabat (Need of Affiliation)

g. Pergi berkemah dengan sahabat (Need of Sentience)

h. Menjadi juara ke tiga dalam lomba mewarnai (Need of Achievement)

i. Teringat akan sosok guru TK saat mengikuti lomba mewarnai (Need of Deference)

j. Cerita LN mengenai prestasi dan kehidupan keluaraganya (Need of Exhibition)

k. Perilaku LN yang kerapkali menolak dan mengeluh saat menjawab pertanyaan peneliti (Need of Rejection)

1. Setelah dibujuk, LN mau untuk mencoba lagi (Need of Counteraction)

m. LN menghindar menjawab pertanyaan peneliti dengan mengajak melakukan hal yang lain (Need of In Avoidance)

n. LN tidak ingin dilarang dan diatur oleh orang lain (Need of Autonomy)

o. LN menyukai kebersihan (Need of Order)

p. Keinginan LN untuk berubah menjadi anak yang baik (Need of Understanding)

\section{PEMBAHASAN DAN KESIMPULAN}

Berdasarkan hasil data yang diperoleh selama proses penelitian berlangsung, peneliti menemukan tiga pola yang membentuk 23 kategori terkait dengan kebutuhan psikologis pada anak dengan gangguan emosi dan perilaku melalui wawancara dan observasi dengan menggunakan metode art therapy. Hirawan (2014) menyatakan bahwa melalui art therapy, seperti kegiatan melukis atau mewarnai, anak dapat mengembangkan ekspresi nonverbal, emosi, menyalurkan ideide, menunjukkan hubungan dan interaksi dengan orang lain serta memberikan kesempatan pada anak untuk menyampaikan ekspresi verbal secara spontan. Seperti penelitan yang dilakukan oleh Perkins (2007) yang berjudul creating containment and facilitating freedom: group art therapy with children with emotional behavioural disorders, menunjukkan bahwa melalui kegiatan art therapy yaitu the animal art project menyediakan media bagi anak dengan attention deficit hyperactive disorder (ADHD) untuk menuangkan kreativitas serta memberikan kesempatan untuk 
mengeksplorasi masalah-masalah pribadi anak ADHD serta melihat hubungan dan interaksi dalam kelompok.

Pada penelitian ini dirancang beberapa kegiatan art therapy sebagai suatu metode wawancara yang digunakan untuk mengetahui gambaran kebutuhan psikologis pada LN yang terganggu emosi dan perilakunya. Pemilihan kegiatan art therapy disesuaikan dengan usia dan kemampuan LN yang berusia 12 tahun dan masih duduk di bangku kelas tiga sekolah dasar. Melalui kegiatan art therapy, LN dapat menunjukkan dengan bebas ekspresi emosi dan perilaku terkait dengan kebutuhan psikologisnya. Selama proses penelitian berlangsung, LN menunjukkan 16 bentuk kebutuhan psikologis. Beberapa kebutuhan psikologis LN tidak terpenuhi dengan baik. hal tersebut dapat diketahui dengan melihat hubungan subjek dengan keluarga, teman sekolah, dan perilaku LN terhadap lingkungan sekitarnya.

Perbedaan perlakuan antar anggota keluarga terhadap LN, menyebabkan LN menunjukkan respon, baik secara perilaku maupun emosional yang berbeda terhadap setiap anggota keluarga. Hurlock (1980) menyatakan bahwa hubungan keluarga mempengaruhi penyesuaian diri anak di lingkungan luar rumah. Sikap orangtua sangat menentukan hubungan keluarga sebab sekali hubungan terbentuk maka hubungan tersebut akan cenderung bertahan. Menurut Fabes dkk. (dalam Papalia et al., 2010), ketika orangtua menunjukkan ketidaksetujuan atau menghukum, emosi negatif yang ditunjukkan bisa jadi semakin intens dan dapat merusak penyesuaian sosial anak.

Perbedaan perlakuan keluarga terhadap subjek menyebabkan tidak terpenuhinya kebutuhan subjek akan pertolongan dalam kesusahan (Need of Succorance). LN kurang mendapatkan perhatian dan kasih sayang dari ibunya, sedangkan ayah LN yang selalu melindungi LN (Need of Harm Avoidance) pun sangat jarang berada di dekat LN karena tuntutan pekerjaan. Ketika ibu LN berperilaku kasar terhadap LN, maka LN akan membela diri dengan membentak (Need of Defendance) kemudian LN mau untuk menuruti perintah ibunya tersebut. Perilaku patuh LN tersebut menunjukkan bahwa LN memenuhi kebutuhannya yaitu dengan tunduk terhadap kekuatan luar (Need of Abasement). Tindakan LN untuk tetap patuh tersebut menunjukkan mekanisme pertahanan diri menurut Freud yaitu reaction formation. Freud (dalam Feist \& Feist 2010) menjelaskan bahwa reaction formation merupakan salah satu cara agar dorongan yang ditekan tersebut bisa disadari adalah dengan cara menyembunyikan diri dalam tindakan atau perilaku yang bertentangan dengan perilaku aslinya.

Ketika LN merasa kesal dan marah terhadap perilaku kasar ibunya tersebut, LN tidak segan untuk memukul atau menyingkirkan benda-benda yang ada di sekelilingnya (Need of Aggression). Perilaku agresi yang dilakukan oleh LN tersebut merupakan salah satu bentuk pengalihan atau displacement menurut Freud (dalam Feist \& Feist, 2010). Perilaku agresi yang ditunjukkan oleh LN merupakan bentuk perilaku yang sama seperti saat ibu berperilaku kasar terhadap LN. Hartini (2009) mengungkapkan bahwa perilaku agresi pada anak dapat terjadi antara lain karena faktor belajar. Thorndike dan Watson (dalam Hergenhahn \& Olson, 2010) menyatakan bahwa belajar berasal dari direct experience, yaitu belajar terjadi sebagai hasil dari interaksi seseorang dengan lingkungannya. Dari interaksi ketika LN mendapat perlakuan kasar dari ibunya, LN merasakan marah dan dendam kemudian berperilaku agresi baik fisik mau pun verbal, sama seperti dengan yang ditunjukkan oleh ibunya. Perilaku agresi LN tersebut juga muncul pada situasi yang membuat LN menjadi kurang nyaman atau yang tidak menyenangkan bagi dirinya.

Dilihat berdasarkan kategori usia LN yang saat ini menginjak 12 tahun, maka saat ini LN termasuk dalam periode masa anak-anak akhir. Menurut Papalia et al. (2010), pada periode masa anak-anak akhir, anak-anak belajar mengenai hal-hal atau situasi yang membuat anak-anak menjadi merasakan marah, senang, sedih atau takut dan bagaimana orang lain bereaksi dalam menunjukkan emosi-emosi tersebut dan anak-anak juga belajar mengadaptasi perilaku dengan emosi tersebut. Emosi yang ditunjukkan oleh LN sesuai dengan kriteria emosi anak dengan gangguan emosi dan perilaku yang dijelaskan oleh Somantri (2007), yaitu ketidakmampuan mengekspresikan emosi secara tepat, kehidupan emosi yang tidak stabil, dan pengendalian diri yang kurang sehingga anak dengan gangguan emosi dan perilaku seringkali menjadi sangat emosional.

LN yang memiliki gangguan emosi dan perilaku dapat membina hubungan yang baik dengan sahabatsahabatnya di sekolah seperti anak pada umumnya. Hubungan yang baik antara LN dengan sahabat-sahabatnya tersebut LN tunjukkan melalui kebutuhan psikologisnya, yaitu LN tidak ingin dilupakan oleh sahabat-sahabatnya (Need of Affiliation) dan keinginan subjek untuk pergi berkemah dengan sahabatsahabatnya tersebut (Need of Sentience). Hal tersebut dijelaskan oleh Hurlock (1980) yang mengemukakan bahwa pada periode masa anak-anak akhir sering disebut juga sebagai usia berkelompok, karena ditandai dengan adanya minat terhadap aktivitas teman-teman, meningkatnya keinginan yang kuat untuk diterima sebagai anggota suatu kelompok dan akan merasa kesepian dan tidak puas bila tidak bersama dengan teman-temannya.

Somantri (2007) menyatakan tidak berarti bahwa anak dengan gangguan emosi dan perilaku sama sekali tidak memiliki kemampuan untuk membentuk hubungan sosial dengan orang lain. Anak dengan gangguan emosi dan perilaku ternyata dapat menjalin hubungan sosial yang sangat erat dengan teman-temannya, bahkan mereka mampu membentuk suatu kelompok yang kompak dan akrab serta membangun 
keterikatan antara yang satu dengan yang lainnya. Namun, di Turiya School LN menolak memulai untuk menjalin hubungan pertemanan dengan anak lainnya yang usianya lebih kecil dari LN (Need of Rejection). Papalia et al. (2010) menyatakan bahwa adanya jarak usia yang telalu lebar tampaknya membuat LN merasakan perbedaan dan kurang tertarik untuk berkenalan hingga menjalin hubungan pertemanan. Terkait dengan kebutuhan LN untuk menolak sesuatu yang kurang menyenangkan bagi dirinya juga ditunjukkan pada saat LN menolak untuk menggambar orang. Berdasarkan pernyataan oleh psikolog yang menangani LN, perilaku menolak LN tersebut menunjukkan bahwa konsep diri pada LN mengalami gangguan sehingga LN enggan menunjukkannya dengan cara menolak untuk menggambar orang. Terganggunya konsep diri LN sangat dipengaruhi oleh pengalaman-pengalaman LN terkait dengan hubungannya dengan keluarga, sekolah dan lingkungan sekitar.

Soetjiningsih (2012) menyatakan bahwa berbagai penelitian telah menunjukkan bahwa hambatan dalam perkembangan sosial-emosional berakibat pada munculnya masalah-masalah akademis. Hal tersebut juga muncul pada diri LN, yaitu LN yang sampai saat ini masih belum mampu untuk membaca, menulis dan berhitung, sehingga LN mengalami tinggal kelas sebanyak dua kali. Rendahnya prestasi belajar anak dengan gangguan emosi dan perilaku di sekolah, diduga karena anak kehilangan minat belajar dan konsentrasi belajar rendah akibat gangguan emosi (Moerdiani dalam Efendi, 2008).

Berdasarkan pemaparan diatas, maka dapat dilihat bahwa tingkah laku dan emosi yang ditunjukkan oleh LN sangat erat sekali kaitannya dengan upaya LN dalam memenuhi kebutuhan hidupnya, terutama kebutuhan psikologisnya. Efendi (2008) menyatakan bahwa beberapa perilaku yang seringkali ditampakkan oleh anak dengan gangguan emosi dan perilaku merupakan bagian dari upayanya untuk melakukan penyesuaian terhadap lingkungan sosial. Akan tetapi karenanya akan menimbulkan persoalan, antara lain perilaku agresif, regresi, proyeksi, rasionalisasi, kompensasi, destruksi dan sejenisnya.

Adapun saran untuk keluarga dari anak dengan gangguan emosi dan perilaku adalah keluarga diharapkan dapat memahami hambatan-hambatan terkait dalam mengenal dan mengekspresikan emosi dan perilaku serta terkait kebutuhan psikologis yang dimiliki oleh anak dengan gangguan emosi dan perilaku. Sehingga pemahaman tersebut dapat dijadikan sebagai acuan dalam menghadapi dan mengasuh anak dengan gangguan emosi dan perilaku kedepannya. Bagi praktisi lainnya, diharapkan dapat menggunakan art therapy sebagai media terapi yang dapat membantu mengatasi dan memahami anak berkebutuhan khusus. Sedangkan, untuk penelitian selanjutnya diharapkan dapat menambahkan jumlah subjek guna mendapatkan hasil data yang lebih mendalam dan dapat menggambarkan fenomena terkait dengan kebutuhan psikologis pada anak dengan gangguan emosi dan perilaku serta diharapkan juga dapat merancang dan menggunakan kegiatan art lainnya yang lebih bervariasi dan kreatif.

\section{DAFTAR PUSTAKA}

Adriani, S. N. \& Satiadarma, M. P. (2011). Efektifitas art therapy dalam mengurangi kecemasan pada remaja pasien leukemia. Indonesian Journal of Cancer Vol. 5 No. 1, 3147. Diunduh tanggal 17 Mei 2015.

Ahmadi, R. (2014). Metodologi penelitian kualitatif. Yogyakarta: AR-Ruzz Media.

Atmodiwirjo, E. T. (2008). Perkembangan anak - suatu tinjauan dari sudut psikologi perkembangan. Dalam Singgih D. Gunarsa \& Ny. Y. Singgih D. Gunarsa, Psikologi perkembangan anak dan remaja. Jakarta: Gunung Mulia.

Atwater, E. (1983). Psychology adjustment, second edition. USA: Prentice-Hall.

Buchalter, S. I. (2009). Art therapy techniques and application. London: Jessica Kingsley Publisher.

Creswell, J. W. (2007). Qualitative inquiry and research design: choosing among five approaches, second edition. London: Sage.

Damayanti, D. (2007). Kebutuhan psikologis remaja yang dititipkan orang tuanya di panti asuhan. Skripsi (tidak dipublikasikan), Fakultas Psikologi, Universitas Katolik Soegijapranata, Semarang. Diunduh tanggal 9 April 2015.

Delphie, B. (2006). Pembelajaran anak berkebutuhan khusus (dalam setting pendidikan inklusi). Bandung: PT Refika Aditama.

Edwards, D. (2004). Art therapy. London: Sage.

Efendi, M. (2008). Pengantar Psikopedagogik Anak Berkelainan. Jakarta: PT Bumi Aksara.

Farrell, P. (1995). Emotional and behavioral difficulties: causes, definition and assessment. Dalam Peter Farrell, Children with emotional and behavioral difficulties: strategies for assessment and intervention. London: The Falmer Press.

Fawcett, M. (2000). Historical views of childhood. Dalam M. Boushel, M. Fawcett \& J. Selwyn, Focus on early childhood: principles and reaities. USA: Blackwell Publishing Company.

Feist, J. \& Feist, G. J. (2010). Teori kepribadian, edisi 7. Jakarta: Salemba Humanika.

Goble, F. G. (1987). Mazhab ketiga: psikologi humanistik Abraham Maslow. Alih bahasa A. Supratiknya. Yogyakarta: Kanisius.

Goleman, D. (2015). Emotional Intelligence. Alih bahasa T. Hermaya. Jakarta: PT Gramedia Pustaka.

Gunarsa, S. D. (2008). Memadu rangsang lingkungan untuk memacu perkembangan anak. Dalam Singgih D. Gunarsa \& Ny. Y. Singgih D. Gunarsa, Psikologi perkembangan anak dan remaja. Jakarta: Gunung Mulia.

Gunawan, A. W. (2013 agustus). Konflik orang tua dan anak sebagai sumber gangguan emosi dan perilaku. Diunduh dari http://www.adiwgunawan.com/?p=article\&action=showne ws\&pid=167 7 April 2015. 


\section{A. A. A. W. D. ANGGASWARI DAN I. G. P. W. BUDISETYANI}

Hall, C. S. \& Lindzey, G. (1993). Psikologi kepribadian 2: teori-teori holistik (organismik-fenomenologis). Alih bahasa A. Supratiknya. Yogyakarta: Kanisius.

Hallahan, D P., Kauffman, J. M. \& Pullen, P. C. (2009). Exceptional Learners: an introduction to special education, eleventh edition. USA: Pearson.

Hartini, L. (2009). Agresi anak yang tinggal dalam keluaraga dengan kekerasan rumah tangga. Skripsi (tidak dipublikasikan). Fakultas Psikologi, Universitas Gunadarma Jakarta. Diunduh tanggal 10 Juli 2015.

Hergenhahn, B. R. \& Olson, M. H. (2010). Theories of learning (teori belajar), edisi ketujuh. Alih bahasa Tri Wibowo B. S. Jakarta: Kencana Prenada Group.

Hirawan, A. (2014). Art is fun (peony's busy book). Jakarta: PT Elex Media Komputindo.

Hurlock, E. B., (1980). Psikologi perkembangan: suatu pendekatan sepanjang rentang kehidupan. Alih bahasa Istiwidayanti dan Soedjarwo. Jakarta: Erlangga.

Lowenstein, L. (2011). Favorite therapeutic activities for children, adolescents, and families: practitioners share their most affective interventions. Toronto: Champion Press.

Maisyarah. (2013). Kecemasan ditinjau dari kebutuhan dasar yang belum terpenuhi. Jurnal Online Psikologi Vol. 1 No.1, 143158. ISSN: 2301-8259 diunduh tanggal 2 Mei 2015.

Malchiodi, C. A. (2003). Handbook of art therapy. New York: The Guilford Press.

Matsumoto, D. \& Juang, L. (2008). Culture and psychology, fourth edition. Belmont: Tomson.

Missa, D. Y. (2014 Juli). Kebutuhan dasar anak. Diunduh dari http://www.kompasiana.com/atonimeto/kebutuhan-dasaranak_54f690eba3331137028b50c7 2 Mei 2015.

Murtie, A. (2014). Ensiklopedi anak berkebutuhan khusus. Yogyakarta: Redaksi Maxima.

Nuryanti, L. (2008). Psikologi anak. Jakarta: PT Indeks.

Papalia, D.E., et al. (2010). Human development (Psikologi Perkembangan). Alih bahasa A. K. Anwar. Jakarta: Kencana Prenada Media Group.

Pawitri, Rahayu. (2014 Juli). Berbagai jenis gangguan emosi anak. Diunduh dari http://id.theasianparent.com/terapi-emosiuntuk-anak/2/ 23 Juli 2014.

Perkins, S. (2007). Creating containment and facilitating freedom: group art therapy with children with emotional behavioural disorders. A research paper. The Departemen of creative arts therapies, Concordia University. ISBN : 978-0-49434763-8 diunduh pada tanggal 2 Mei 2015.

Poerwandari, E K. (1998). Pendekatan kualitaitif dalam penelitian psikologi. Jakarta: LPSP3.

Purnomo, H. B. (1990). Memahami dunia anak-anak. Bandung: CV Mandor Maju.

Santoso, G. A. \& Royanto, L. R. M. (2009). Teknik penulisan laporan penelitian kualitatif. Jakarta: LPSP3.

Santrock, J.W. (2002). Life span development:perkembangan masa hidup, edisi 5, jilid 1. Alih bahasa Juda Damanik dan Achmad Chusairi. Jakarta: Erlangga.

Satori, D. \& Komariah A. (2014). Metodologi penelitian kualitatif. Bandung: Alfabeta.

Shokiyah, N. N. (2014). Analisis hubungan antara kegiatan melukis dengan kebutuhan psikologis pada remaja. Jurnal Seni
Budaya Vol. 12 No.1, 37-43. Diunduh tanggal 17 Mei 2015.

Slavin, R. E. (2008). Psikologi pendidikan: teori dan praktik, edisi kedelapan, jilid 1. Alih bahasa Marianto Samosir. Jakarta: PT Indeks.

Soetjiningsih, C. H. (2012). Perkembangan anak sejak pertumbuhan sampai dengan kanak-kanak akhir. Jakarta: Prenada Media Group.

Somantri, S. (2007). Psikologi anak luar biasa. Bandung: PT Refika Aditama.

Stewart, C J. \& Cash, W. B. (2008). Interviewing: principles and practices. New York: McGraw-Hill.

Sugiyono. (2013). Metodologi penelitian kombinasi (mix method). Bandung: Alfabeta.

The British Association of Art Therapist. (2014). What is art therapy?. Diunduh dari https://www.google.com/url?sa=t\&rct=j\&q=\&esrc=s\&sour ce $=$ web $\& c d=5 \&$ ved $=0$ CEAQFjAEahUKEwjw3qfg-bGAhVSGY4KHUWCAG8\&url=http\%3A\%2F\%2Fwww. baat.org\%2FAssets $\% 2$ FDocs $\% 2$ FGeneral $\% 2$ FART $\% 2520$ THERAPY\%2520TRAINING\%2520July\%2520\%2520201 4.pdf\&ei=U3mrVbDpHNKyuATFhIL4Bg\&usg=AFQjCN E7PoUzJOYKSVsCuLknjs2HOl42Rg\&cad=rja 7 April 2015. 